\title{
DE

DE GRUYTER

OPEN

\section{PREDICATE OFFENCES OF MONEY LAUNDERING AND ANTI MONEY LAUNDERING PRACTICES IN BANGLADESH AMONG SOUTH ASIAN COUNTRIES}

\author{
ISLAM Mohammad Saiful \\ Leading University, Sylhet, Bangladesh \\ EVA Sharmin Akter \\ Dhaka University, Bangladesh \\ HOSSAIN Mohammad Zahed \\ Leading University, Sylhet, Bangladesh
}

\begin{abstract}
:
The purpose of the study is to identify the main reasons of money laundering in Bangladesh among the twenty seven predicate offences of money laundering prescribed by Bangladesh Bank and position of Bangladesh among South Asian Countries regarding anti-money laundering practices. Besides, an anti-money laundering model has been developed to combat against money laundering as 14 percent bankers think that only existing know your customer form and transaction profile of banking sector are not enough to detect money laundering. To conduct the study, 91 bankers have been surveyed to take response through structured questionnaire regarding their opinion about the predicate offences of money laundering and sufficiency of existing KYC form of banking sector to detect money laundering. From the responses, factor analysis, test of hypothesis, correlation and regression analysis have been conducted using SPSS software. The study identifies that predicate offences of money laundering can be minimized mainly through scrutinizing the activities of local criminals with foreign network and strict anti-corruption measures through automation in National Board of Revenue, strict policy adoption of criminal detection and support from foreign experts. Besides, regression model shows that only six predicate offences of money laundering explains 87.2 percent of money laundering that should get more emphasize to combat against money laundering. From the comparative analysis, it has been found that Bangladesh in holding better position just after India among six South Asian Countries according to Basel AML Index score. This study provides a complete understanding of the position of Bangladesh in case of money laundering and anti-money laundering practices. The integration of four domains, i.e. AML model development, factor analysis, econometric analysis and comparative analysis of AML index will provide insights to managers and policy makers about the money laundering scenario in Bangladesh.
\end{abstract}

Key words: Money Laundering; Predicate Offences; Corruption; Tax; Bangladesh Bank 


\section{Introduction}

Money laundering can be defined as knowingly moving, converting or transferring proceeds of crime or property involved in an offence for the purposes of concealing the elicit origin, location, source, ownership or control of proceeds of crime; or assisting any person for evading the legal consequence of his or her action who is involved in the commission of the predicate offence. Besides, money laundering includes smuggling funds or property abroad earned through illegal or legal means, knowingly remit the proceeds of crime into or out of Bangladesh in order to hide its illegal source, concluding or attempt to conclude financial transaction to avoid reporting requirement under this act, converting property in order to assist the carrying out of a predicate offence, acquiring or using property knowing that such property is the proceeds of a predicate offence, performing such activities so that illegal source of the proceeds of crime may be concealed; participating in, associating with, conspiring to commit, attempting to commit or counsel to commit any offences mentioned above. Predicate offences of money laundering means offences committed within or outside the country, the money or property derived from which is laundered or attempt to be laundered. There are twenty eight predicate offences of money laundering declared by Bangladesh Bank. Money laundering is committed through three stages that includes placement of fund in any bank account from the source of any predicate offence, layering of fund through multiple financial transactions and integration of fund to convert the fund into legal fund through investment in several sectors as real estate. Money laundering differs from terrorist financing. Any individual or organization wants to hide personal gain in case of money laundering where any individual or organization wants to establish any special ideology in case of terrorist financing.

\section{Rational of the study}

Since the last few years, money laundering has become a global issue. But, it has been rarely found to identify the vital predicate offences of money laundering among the large number of predicate offences to put more emphasize for taking preventive measures in that particular sectors of money laundering (Karim, 2016). The research gaps identified from several literature review may include lack of contemporary survey to the bankers to find out the major dimensions of predicate offences of money laundering, developing unique model of anti-money laundering and showing comparative position of Bangladesh among South Asian countries. In this context, major predicate offences of money laundering have been identified through contemporary survey to 91 bankers and an anti-money laundering model has been developed instigating DIB report. Besides, the study has shown the position of Bangladesh among South Asian countries regarding risk of money laundering. At the end of the research paper, some measures have been suggested for prevention of the significant predicate offences to improve in anti-money laundering practices in Bangladesh. 


\section{Objective of the Study}

- To depict the situation of money laundering and anti- money laundering practices in Bangladesh

- To develop an unique anti-money laundering model for banking sector in Bangladesh

- To identify the vital predicate offences which are responsible for money laundering

- To take opinion of bankers regarding adequacy of existing KYC form and TP to combat against money laundering

- To identify the position of Bangladesh among South Asian countries regarding anti- money laundering practices

- To recommend some measures for combating against money laundering based on improvement in preventing significant predicate offences

\section{Research Methodology}

4.1. Type of research: The research is empirical in nature. To substantiate the findings of the paper comprehensively, theoretical analysis along with numerical evidences has been used. Data has been presented in the simple and logical form (Kothari, 2001).

4.2. Data Sources: Both primary and secondary data sources have been used to conduct the research. As a source of primary date, a survey has been conducted through structured questionnaires focusing on opinion regarding vital predicate offences of money laundering taking total 91 individuals including senior bankers serving in commercial banks as sample size.

Secondary data were collected from economic reviews, journals, different websites etc. to develop the theoretical background of the study. Data of Basel AML index of last five (2012-2016) years have been taken into consideration. Data generated from different sources were compared critically to ensure insignificant mismatching in material facts (Gujarati, 2012).

4.3. Variables Covered: The factor analysis regarding predicate offences of money laundering with the factors and variables covered is shown in Table-01 of appendix.

4.4. Sampling Method: Purposive sampling has been adopted for conducting the study. Total 91 structured questionnaires were provided among the respondents as total sample size. The survey was conducted in August 2016.

4.5. Survey Instrument: One structured questionnaire was developed having five (5) facets of predicate offences of money laundering which was addressed through 27 
statements. The respondents were asked to response using a five- step Liker scale ranging from strongly disagree (1) to strongly agree (5).

4.6. Data Analysis Tools: Data has been analyzed using SPSS 20 to conduct factor analysis, test of hypothesis, correlation and regression. Besides, Microsoft Excel has been used to show year to year comparative trend analysis among South Asian countries. Different statistical tools have been used to asses and interpret the statistical outputs.

\section{Limitation of the Study:}

- It became difficult to take more sample into consideration as respondents were not interested to disclose confidential opinion.

- Purposive sampling rather than random sampling has been used to conduct the survey.

\section{Review of Literature}

Yeandle, Mainelli, Berendt and Healy (2005: 8,52) in their research paper named "Anti- Money Laundering Requirements: Costs, Benefits and Perceptions" have assessed the perceived costs and benefits of Anti- Money Laundering requirement of UK compared with USA, Italy, France and Germany. The research paper concludes that Anti Money Laundering related cost of UK seems higher than USA, Italy, France and Germany but this higher cost is not generating greater benefits for UK based organizations. (Ferwerda , 2008: 10-15) in his study titled "The Economics of Crime and Money Laundering: Does Anti-Money Laundering Policy Reduces Crime?" has identified the effect of anti-money laundering policy on the crime rate. Hence, he has drawn the conclusion that the probability to be convicted for the predicate crime, the probability to be caught for money laundering, the transaction cost of money laundering and the sentence for money laundering are negatively related to the amount of crime. (ESAAMLG, 2009: 6-9) in its report titled "An Assessment of the Links between Corruption and the Implementation of Anti- Money Laundering Strategies and Measures in the ESAAMLG Region" has shown the impact of corruption on the implementation of anti-money laundering strategies. The report suggests that member countries of ESAAMLG should adopt institutional and legislative frameworks to ensure collaboration between the agencies which are responsible for investigating money laundering and corruption. (Schneider, 2010: 24-25) in his research paper titled "Money Laundering and Financial Means of Organized Crime: Some Preliminary Empirical Findings" has made a review the applied literature of money laundering to tackle the difficult topic of estimating the volume of money laundering. The paper concludes that as Germany has no powerful and efficient international organizations to fight against money laundering and organized crime, fighting against organized crime and money laundering is extremely difficult. (FATF, 2010: 59) in its report titled "Global 
Money Laundering and Terrorist Financing Threat Assessment" has concluded that in order to fund Anti Money Laundering programmes, safety effort and other public policy, all countries must deal with challenges of allocating scarce resources.

Proposed Anti-Money Laundering Model: An AML model can be developed through following mechanism targeting the steps of money laundering such as placement, layering and integration to combat against money laundering.

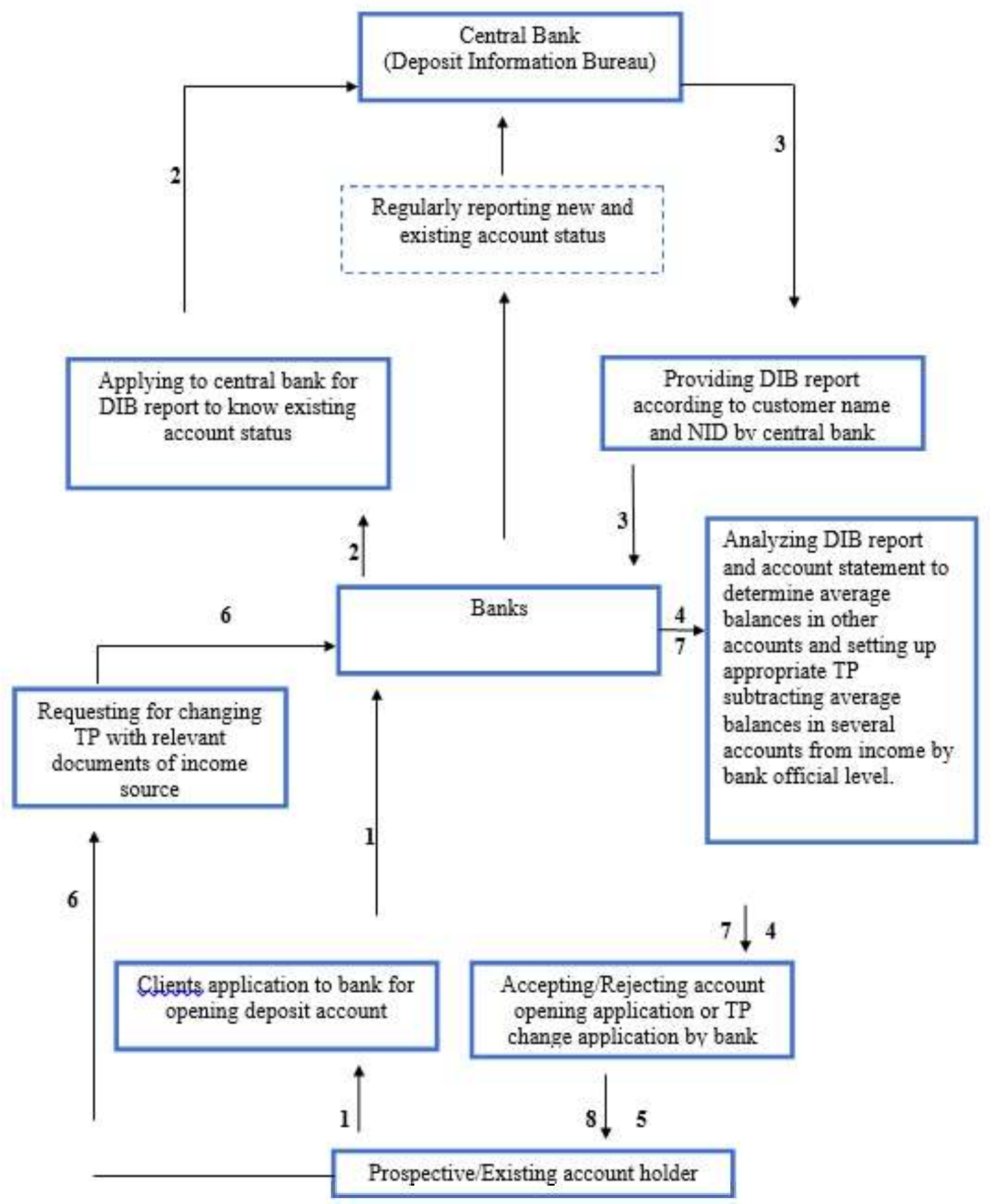


1. Customer will apply to the respective bank filling up account opening form.

2. Bank will apply for Deposit Information Bureau Report of customer to Deposit Information Bureau of central bank (Bangladesh Bank).

3. Central bank (Bangladesh Bank) will provide DIB report to the bank according to provided customer name and National Identification Number.

4. Bank will analyze DIB report to identify existence of any other account and average balance in other accounts. Bank will compare the average balance with the reported income level to find out whether there is any income left to deposit in the proposed deposit account. Bank can also take account statements of other banks to verify the income source.

5. If there is any income left to be deposited in the proposed bank account bank can open proposed deposit account setting up appropriate transaction profile limiting the maximum amount of deposit up to the amount left after subtracting average deposit in all existing bank accounts. Bank will also limit the amount of withdrawal up to the limit of maximum deposit for the particular period (1 month). If income level of customer does not support the requirement of opening proposed deposit account bank can reject the proposal of opening bank account.

6. Existing customers can apply for changing Transaction Profile showing relevant evidence of changed income level and closed deposit account in any other bank.

7. Bank will properly verify the provided documents of change in income level and account information of other banks.

8. Bank can change transaction profile verifying the provided documents or reject the proposal.

\section{Statistical Results and Findings}

From the econometric analysis, findings of the study are categorically discussed in the following subsections:

7.1 Factor Analysis on Predicate Offences of Money Laundering: In this study, descriptive statistics indicated a number of reasons which are responsible for money laundering in Bangladesh from which we have adopted factor analysis to identify the major dimensions by reducing the number of reasons. The analysis used principal component method to extract the factors with varimax rotation technique. Table 1 shows the results of the factor analysis of predicate offences of money laundering in Bangladesh. A particular variable has been selected to include as a factor on the basis of high correlation value (factor loadings). The study determined six main factors as the predicate offences of money laundering in Bangladesh (Kothari, 2001). These factors are:

Factor I: Human trafficking, Illegal trade in narcotic (sedative) drugs, psychotropic substances and substances causing intoxication, Illegal trade in stolen and other 
goods, Smuggling of domestic and international currency, Terrorism or financing in terrorist activities, Trafficking of women and children, Murder, grievous bodily harm, Illegal trade of firearms, Dowry, Kidnapping, illegal restrains and hostage taking, Adulteration or the manufacture of goods through infringement of title, Smuggling and offences related to customs and excise duties, Counterfeiting (imitating) deeds and documents, Racketeering (illegal enterprise for profit), Insider trading and market manipulation in capital market.

Factor II: Forgery, Fraud, Corruption and bribery

Factor III: Black marketing

Factor IV: Counterfeiting (imitating) currency, Infringement of intellectual property rights

Factor V: Offences related to environment

Factor VI: Tax related offences

The respective magnitudes of factor loadings depict the significance of a particular element in a factor and these elements are arranged in order of their magnitudes respectively. The predicate offences consisting Factor-I are mainly related to cross boarder criminal activities, offences conducted by individual and organizations to maximize income level and profiteering from criminal activities and crimes for life and livelihood due to lack of employment opportunity. The predicate offences of Factor-II are related to criminal activities through red tapism in private and public organizations. Factor -III is regarding profiteering from creating artificial crisis in market to maximize price. Factor -IV is associate with circulating fake note and violating human rights. Factor $-\mathrm{V}$ is related to hiding personal gain generating from making environmental hazard. Factor $-\mathrm{VI}$ is related to evading tax through hiding income sources and wealth in tax return.

7.2 Econometric Analysis: From factor analysis, some important predicate offences of money laundering have been identified as independent variables based on factor loading above 0.70 to conduct econometric analysis. Predicate Offences of Money Laundering (PML) has been considered as dependent variable. On the other hand, Human trafficking (HT), Illegal Trade in Narcotic (sedative) Drugs (ITND), Illegal Trade in Stolen and other Goods (ITSG), Smuggling of Domestic and International Currency (SDIC), Forgery (Forgery), Trafficking of Women and Children (TWC) have been taken into consideration as independent variable (Gujarati, 2012). As part of econometric analysis, test of hypothesis, correlation and regression analysis have been conducted.

\subsubsection{Test of Hypothesis:}

In this study, following hypothesis have been developed:

$H_{0}$ : The coefficient of multiple determinations in the population is zero

$H_{1}$ : The coefficient of multiple determinations in the population is not zero

Due to the nature of variables and availability of information, analysis of variance (ANOVA) has been used to test the above hypothesis. The statistical method of F-test has been used at $5 \%$ level of significance to identify whether there are significant 
relationship between predetermined predicate offences responsible for money laundering and above mentioned nine six independent variables. In this regard, we can accept null hypothesis if the calculated $p$ (Significance) value is greater than 0.05 and we can reject the null hypothesis if the calculated $p$ (Significance) value is less than 0.05 (Gujarati, 2012).

From the Table 03 of appendix, it has been found that the value of $p$ (Significance) is 0.000 against all the independent variables which is less than 0.05 . Hence, the null hypothesis is rejected. Thus, we can conclude that there is significant relationship between the independent variables and dependent variable. Besides, the value of $R$ is 0.872 according to Table 02 of appendix which indicates that there is high degree of positive correlation among the above mentioned independent and dependent variables.

\subsubsection{Regression analysis:}

The standardized regression model is:

$$
P M L=\alpha_{0}+\beta_{1} H T+\beta_{2} I T N D+\beta_{3} I T S G+\beta_{4} S D I C+\beta_{5} \text { Forgery }+\beta_{5} T W C \ldots \ldots .
$$

The fitted regression model is:

$P M L=34.17+.321(H T)+.145(I T N D)+.227($ ITSG $)+.210($ SDIC $)+.089($ Forgery $)+.194($ TWC $)$

According to Table 01 of appendix, the value of $\mathrm{R}^{2}$ is 0.872 or $87.2 \%$ which indicates that $87 \%$ of variation in the dependent variables (predicate offences of money laundering) can be explained by the above mentioned regression model. The value of adjusted $\mathrm{R}^{2}$ is .859 or $85.9 \%$ which suggests that addition of other independent variables will not make any contribution to explain the variation in the dependent variable (Kothari, 2001).

\subsection{Existing KYC form of Banking Sector to Combat against Money Laundering:}

From the survey of 91 bankers regarding their opinion toward adequacy of existing $\mathrm{KYC}$ form to combat against money laundering following statistical output has been found:

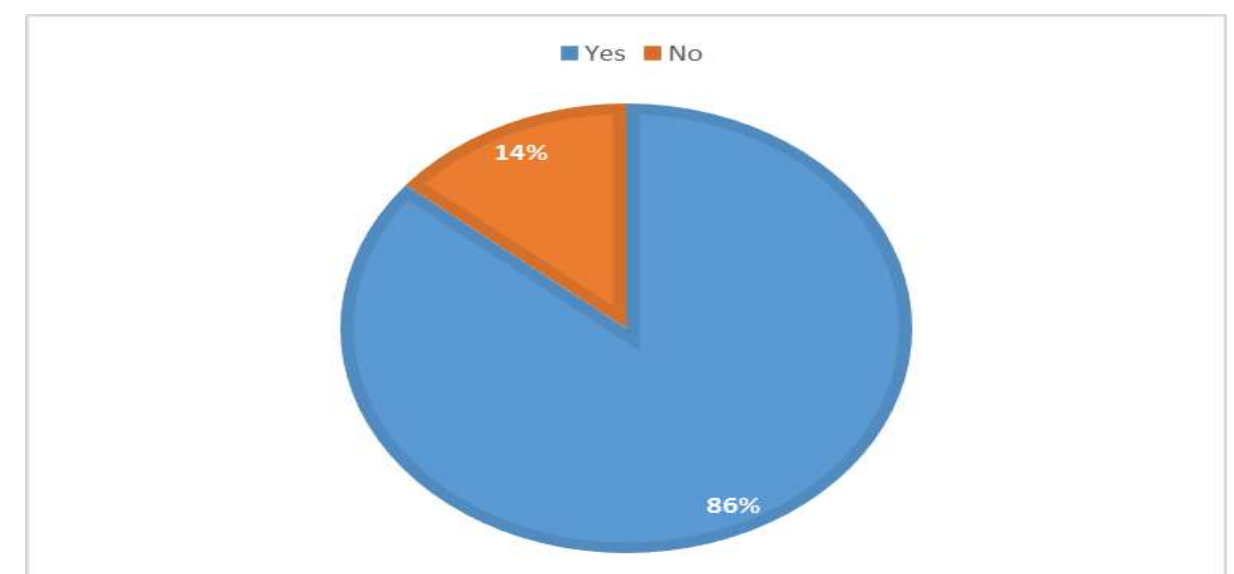

Figure 1: Bankers' Perspective toward Adequacy of KYC Form to Combat Money Laundering 
From the above figure, we have found that 86 percent bankers opines that existing KYC form of banking systems is performing adequately to find out the issue of money laundering through bank accounts. On the other hand, 14 percent bankers think that existing KYC form of banking system is not adequate to combat against money laundering strictly. They think that existing KYC form needs significant change and upgradation according to changing situations taking place in case of handling money laundering (Kothari, 2001).

\subsection{Comparative Trend Analysis of Anti Money Laundering Practices in South} Asian Countries: The Basel AML index, developed by Basel Institute on Governance, assess the risk of money laundering since 2012 based on publicly available sources to indicate the vulnerability of a country in this regard rather than assessing the amount of illicit money or transaction. According to Basel index report, 14 indicators that deal with Anti Money Laundering and combating the financing of terrorism such as corruption, political disclosure, regulations, financial standard etc. are considered to assign one overall risk score.

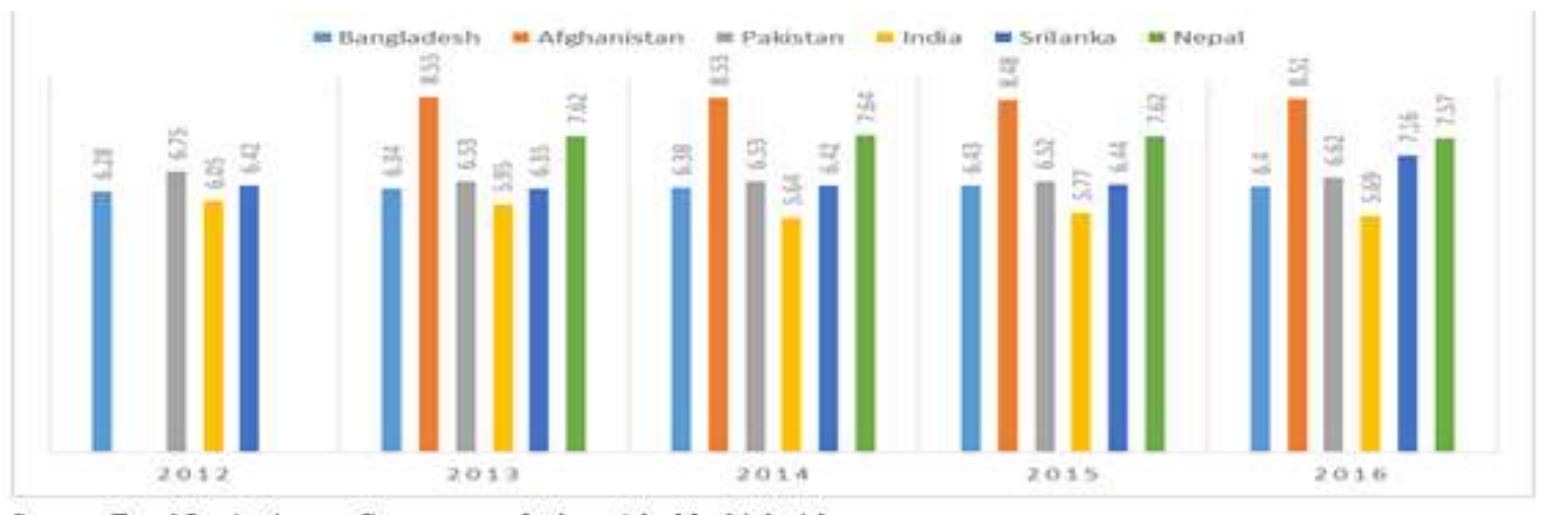

Source: Basel Institution on Governance, $0=$ low risk, $10=$ high risk

*Bhutan and Maldives not included in the index

Figure 2: Basel AML Index of South Asian Countries

From the above figure, we have found that Bangladesh has been placed $5^{\text {th }}$ after India among the six South Asian Countries since last four years according to AML Index. AML index 2016 has covered 149 countries where Bangladesh has score of $6.40\left(54^{\text {th }}\right)$ followed by India with 5.69 (78 th $)$ (BIG, 2016). However, Afghanistan, Nepal, Srilanka and Pakistan are standing out with high risk score with $8.51\left(2^{\text {nd }}\right), 7.57$ $\left(12^{\text {th }}\right), 7.16\left(23^{\text {rd }}\right)$ and $6.62\left(45^{\text {th }}\right)$ respectively. Hence, Bangladesh has improved its ranking two steps globally in 2016 as its ranking was $52^{\text {nd }}$ with score of 6.43 in 2015 . Afghanistan is holding highest score with high risk status since its inclusion in the Basel AML index. On the other hand, India is holding the lowest score in last five years among the above mentioned six South Asian countries (Basel Institute on Governance, 2016). 


\section{Conclusions and Recommendations}

On the basis of the findings from factor analysis regarding predicate offences of money laundering we can recommend that predicate offences of money laundering can be solved through scrutinizing the activities of local criminals with foreign network and strict anti-corruption measures that will require automation of National Board of Revenue, strict policy adoption and support from foreign experts to detect criminals in critical cases networking with local law and order enforcing and implementing authority, creating employment opportunity with in the country so that people are not bound to take risk of emigration for life and livelihood or involved in criminal activities. Besides, Deposit Information Bureau of central bank (Bangladesh Bank) can be establish that will generate DIB report to inform the banks about account status of customers to detect money laundering and decision making to open bank accounts. From the comparative analysis of anti- money laundering practices, it has been found that Bangladesh is holding $5^{\text {th }}$ position among six South Asian countries for last four years consistently which indicates that there is ample opportunity to improve in several Anti Money Laundering measures for combating against money laundering collectively and bringing it to the minimum level.

\section{References}

Ahmed, F., 1995. "Performance of Commercial Banks in Bangladesh". Journal of IBB, Vol-36

Bangladesh Bank, Peoples Republic of Bangladesh, Vibrant Bangladesh- A Stable and Potential Economy, Dhaka.

Basel Institu on Governance, (2016), https://index.baselgovernance.org/ranking, Accessed: September 10, 2016.

BIG, Basel Institute on Governance, (2016), Basel AML Index 2016 Report", International centre for asset recovery, pp. 3.

Eastern and Southern Africa Anti-Money Laundering Group, (2009), An Assessment of the Links between Corruption and the Implementation of Anti- Money Laundering Strategies and Measures in the ESAAMLG Region, pp. 6-9.

FATF, (2010) "Global Money Laundering and Terrorist Financing Threat Assessment", pp. 59.

Ferwerda, J. (2008),"The Economics of Crime and Money Laundering: Does Anti-Money Laundering Policy Reduces Crime?", Vol-8-35): pp. 10-15.

Gujarati, D.N, (2012), Basic Econometrics", Fourth edition, pp. 38-49.

Islam, A., "Monetary Policy and Money Supply Process in Bangladesh: An Analytical Review", (2010), pp. 69-75.

Karim, S.S., (2016), "Cyber-Crime Scenario in Banking Sector of Bangladesh: An Overview", Vol- 44, pp. 12-19.

Kothari, C.R. (2001) "Research Methodology: Methods and Techniques". New Age International Publishers, New Dilhi.

Ministry of Finance, Peoples Republic of Bangladesh, "Bangladesh Economic Review 20142015", Dhaka. 
Ministry of Finance, Peoples Republic of Bangladesh, Functions of Banks and Financial Institutions, Dhaka: Various Issues.

Schneider, F. (2010). "Money Laundering and Financial Means of Organized Crime: Some Preliminary Empirical Findings", Economics of Security Working Paper 26, Berlin: Economics of Security, pp. 24-25.

Yeandle, Mainelli, Berendt and Healy, (2005), "Anti- Money Laundering Requirements: Costs, Benefits and Perceptions", Vol-6: pp. 8, 52. 


\section{Appendix}

Table 1: Factor analysis on predicate offences of Money Laundering in Bangladesh

\begin{tabular}{|c|c|c|c|c|c|c|c|}
\hline \multirow[b]{2}{*}{$\begin{array}{l}\text { Predicate Offences of Money } \\
\text { Laundering }\end{array}$} & \multicolumn{7}{|c|}{ Factors } \\
\hline & 1 & 2 & 3 & 4 & 5 & 6 & 7 \\
\hline Corruption and bribery & & .560 & & & & & \\
\hline Counterfeiting (imitating) currency & & & & .599 & & & \\
\hline $\begin{array}{l}\text { Counterfeiting (imitating) deeds } \\
\text { and documents }\end{array}$ & .616 & & & & & & \\
\hline $\begin{array}{l}\text { Extortion (abuse of regulatory } \\
\text { authority) }\end{array}$ & .556 & & & & & & \\
\hline Fraud & & .641 & & & & & \\
\hline Forgery & & .733 & & & & & \\
\hline IIlegal trade of firearms & .684 & & & & & & \\
\hline $\begin{array}{l}\text { IIlegal trade in narcotic (sedative) } \\
\text { drugs, psychotropic substances } \\
\text { and substances causing } \\
\text { intoxication }\end{array}$ & .786 & & & & & & \\
\hline $\begin{array}{l}\text { IIllegal trade in stolen and other } \\
\text { goods }\end{array}$ & .779 & & & & & & \\
\hline $\begin{array}{l}\text { Kidnapping, illegal restrains and } \\
\text { hostage taking }\end{array}$ & .650 & & & & & & \\
\hline Murder, grievous bodily harm & .686 & & & & & & \\
\hline Trafficking of women and children & .706 & & & & & & \\
\hline Black marketing & & & .480 & & & & \\
\hline $\begin{array}{l}\text { Smuggling of domestic and } \\
\text { international currency }\end{array}$ & .768 & & & & & & \\
\hline $\begin{array}{l}\text { Theft or robbery or dacoity or } \\
\text { piracy or hijacking of aircraft }\end{array}$ & .579 & & & & & & \\
\hline Human trafficking & .844 & & & & & & \\
\hline Dowry & 682 & & & & & & \\
\hline $\begin{array}{l}\text { Smuggling and offences related to } \\
\text { customs and excise duties }\end{array}$ & 625 & & & & & & \\
\hline Tax related offences & & & & & & & .563 \\
\hline $\begin{array}{l}\text { Infringement of intellectual } \\
\text { property rights }\end{array}$ & & & & .476 & & & \\
\hline $\begin{array}{l}\text { Terrorism or financing in terrorist } \\
\text { activities }\end{array}$ & .737 & & & & & & \\
\hline $\begin{array}{l}\text { Adulteration or the manufacture of } \\
\text { goods through infringement of title }\end{array}$ & 649 & & & & & & \\
\hline Offences related to environment & & & & & .495 & & \\
\hline Sexual exploitation & .454 & & & & & & \\
\hline
\end{tabular}


Studies in Business and Economics no. 12(3)/2017

\begin{tabular}{|l|l|l|l|l|l|l|l|}
\hline $\begin{array}{l}\text { Insider trading and market } \\
\text { manipulation in capital market }\end{array}$ & .600 & & & & & & \\
\hline $\begin{array}{l}\text { Organized crime and participation } \\
\text { in organized criminal groups }\end{array}$ & .536 & & & & & & \\
\hline $\begin{array}{l}\text { Racketeering (illegal enterprise for } \\
\text { profit) }\end{array}$ & 603 & & & & & & \\
\hline Eigenvalue & 9.52 & 2.74 & 2.04 & 1.75 & 1.35 & 1.23 & 1.22 \\
\hline Percent of variation & 35.247 & 10.14 & 7.56 & 6.47 & 4.98 & 4.55 & 4.52 \\
\hline Cumulative percent of variation & 35.25 & 45.38 & 52.94 & 59.42 & 64.39 & 68.95 & 73.46 \\
\hline KMO=0.764 \& only factor loadings $\geq 0.40$ & has been shown in the Table & \\
\hline
\end{tabular}

Extraction Method: Principal Component Analysis.

Rotation Method: Varimax with Kaiser Normalization.

Source: Field Survey, August 2016

Table 2

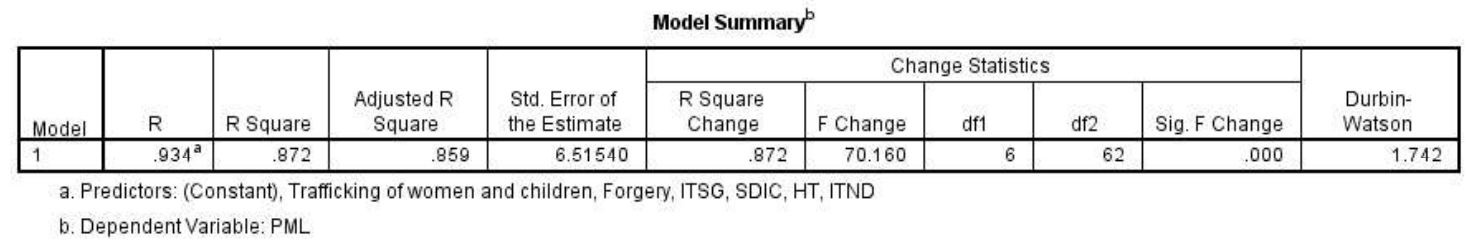

Table 3

ANOVA ${ }^{a}$

\begin{tabular}{|rl|r|r|r|r|r|}
\hline \multicolumn{1}{|c|}{} & \multicolumn{1}{|c|}{$\begin{array}{c}\text { Sum of } \\
\text { Squares }\end{array}$} & df & Mean Square & \multicolumn{1}{c|}{ F } & Sig. \\
\hline 1 & Regression & 17869.899 & 6 & 2978.316 & 70.160 & $.000^{\circ}$ \\
& Residual & 2631.928 & 62 & 42.450 & & \\
& Total & 20501.826 & 68 & & & \\
\hline
\end{tabular}

a. Dependent Variable: PML

b. Predictors: (Constant), Trafficking of women and children, Forgery, ITSG, SDIC, HT, ITND

Table 4

\begin{tabular}{|c|c|c|c|c|c|c|c|c|c|c|c|c|c|}
\hline \multicolumn{14}{|c|}{ Coefficients $^{\mathrm{a}}$} \\
\hline & & \multicolumn{2}{|c|}{ Unstandardized Coefficients } & \multirow{2}{*}{$\begin{array}{c}\begin{array}{c}\text { Standardized } \\
\text { Coefficients }\end{array} \\
\text { Beta }\end{array}$} & \multirow[b]{2}{*}{$t$} & \multirow[b]{2}{*}{ Sig. } & \multicolumn{2}{|c|}{$95.0 \%$ Confidence Interval for B } & \multicolumn{3}{|c|}{ Correlations } & \multicolumn{2}{|c|}{ Collinearity Statistics } \\
\hline \multicolumn{2}{|c|}{ Model } & $B$ & Std. Error & & & & Lower Bound & Upper Bound & Zero-order & Partial & Part & Tolerance & VIF \\
\hline \multirow[t]{7}{*}{1} & (Constant) & 34.165 & 3.600 & & 9.489 & .000 & 26.968 & 41.362 & & & & & \\
\hline & HT & 4.781 & 1.147 & .321 & 4.167 & .000 & 2.487 & 7.074 & .814 & .468 & .190 & .349 & 2.862 \\
\hline & ITND & 1.953 & 1.089 & 145 & 1.794 & .078 & .223 & 4.129 & .780 & .222 & .082 & .317 & 3.154 \\
\hline & ITSG & 3.471 & 1.105 & .227 & 3.142 & .003 & 1.263 & 5.679 & .763 & .371 & .143 & .396 & 2.522 \\
\hline & SDIC & 3.156 & 1.037 & .210 & 3.044 & .003 & 1.084 & 5.229 & .761 & .361 & .139 & .433 & 2.308 \\
\hline & Forgery & 1.333 & .749 & .089 & 1.780 & .080 & -164 & 2.829 & .296 & .221 & .081 & .826 & 1.211 \\
\hline & $\begin{array}{l}\text { Trafficking of women and } \\
\text { children }\end{array}$ & 2.676 & 1.040 & .194 & 2.574 & .012 & .598 & 4.754 & .707 & .311 & .117 & .363 & 2.757 \\
\hline
\end{tabular}

a. Dependent Variable: PML 